\title{
Combined effect of xanthan gum and water content on physicochemical and textural properties of gluten-free batter and bread
}

\author{
Christian R. Encina-Zelada ${ }^{\mathrm{a}, \mathrm{b}, \mathrm{c}}$, Vasco Cadavez ${ }^{\mathrm{a}}$, Fernando Monteiro $^{\mathrm{d}, \mathrm{e}}$, José A. Teixeira ${ }^{\mathrm{b}}$, \\ Ursula Gonzales-Barron ${ }^{\mathrm{a}, *}$ \\ ${ }^{\text {a }}$ CIMO Mountain Research Centre, School of Agriculture, Polytechnic Institute of Bragança, Portugal \\ ${ }^{\mathrm{b}}$ Centre of Biological Engineering, School of Engineering, University of Minho, Portugal \\ ${ }^{c}$ Department of Food Technology, Faculty of Food Industries, National Agricultural University La Molina, Lima, Peru \\ d Department of Electrical Engineering, School of Technology and Management, Polytechnic Institute of Bragança, Portugal \\ e Portugal INESC-TEC - Institute for Systems and Computer Engineering, Technology and Science, Porto, Portugal
}

A R T I C L E I N F O

\section{Keywords:}

Quinoa

Rice

Maize

Hydrocolloid

Rheology

Texture profile analysis

Crumb image analysis

\begin{abstract}
A B S T R A C T
The objective of this study was to evaluate the combined effect of xanthan gum (XG) on physicochemical, rheological and textural properties of gluten-free batter and bread. To prepare gluten-free batter, different levels of XG (1.5, 2.5 and 3.5\%) and water (90, 100 and 110\%) were added to a base formula of rice (50\%), maize (30\%) and quinoa flours (20\%); and the batters were evaluated in a factorial design. Several properties on both batter (stickiness and back extrusion) and its corresponding bread (loaf specific volume, baking loss, water activity and $\mathrm{pH}$, texture profile, mean cell area, mean cell density, cell size uniformity, void fraction, mean cell compactness and mean cell aspect ratio) were then evaluated. Higher XG doses $(\mathrm{p}<.001)$ tended to produce batters of lower stickiness, adhesion and cohesive-strength, yet, of higher firmness, consistency, cohesiveness and viscosity index. After baking, these loaves presented lower specific volume; lower crumb $\mathrm{a}_{\mathrm{w}}, \mathrm{pH}$, hardness, springiness, mean cell area and void fraction; and higher $(\mathrm{p}<.001)$ chewiness, resilience, mean cell density, cell size uniformity and mean cell compactness. The sticker and less consistent batters produced with higher WC rendered larger bread loaves of softer and more springy/resilient crumbs with greater mean cell size and void fraction. Gluten-free loaves of good appearance in terms of higher specific volume, lower crumb hardness, higher crumb springiness, and open grain visual texture were obtained in formulations with $110 \%$ WC and XG doses between 1.5 and $2.5 \%$.
\end{abstract}

\section{Introduction}

During the past two decades, the demand for gluten-free (GF) foods has increased due to the growing number of consumers suffering of gluten intolerance disorder, known as coeliac disease, which is characterised by a permanent intolerance to the gliadin fraction of wheat (Sciarini, Ribotta, León, \& Pérez, 2012), producing damages in the intestinal mucosa through inflammation of the micro-villi and thereby deteriorating the ability to absorb nutrients. To target the $0.5-1.0 \%$ of the world's population estimated to be affected by coeliac auto-immune disease (Gujral, Freeman, \& Thomson, 2012), a number of food products that avoid the use of wheat (gliadin), barley (hordein) and rye (secalins) have been lately developed. It is estimated that, approximately $15 \%$ of worldwide consumers are opting for gluten-free products not only due to dietary restrictions but also as part of what they believe a healthy lifestyle. In these consumers, bread is the most demanded product, which has led to an upsurge in the development of GF bread (Anonymous, 2012).

Extensive research has been devoted to the development of GF bread because baked goods lacking a gluten matrix have poor technological quality, as manifested by their low specific volume, high crumb hardness and high staling rate (Pasqualone et al., 2010; Schober, Messerschmidt, Bean, Park, \& Arendt, 2005; Sciarini, Ribotta, León, \& Pérez, 2010a; Sciarini, Ribotta, León, \& Pérez, 2010b). The addition of hydrocolloids is used to improve the rheological features of GF batter, as these molecules imitate the visco-elastic properties of gluten, and are essential to increase gas retention during proofing, baking, and hence to increase the loaf specific volume (Hager \& Arendt, 2013).

Xanthan gum, a polysaccharide produced by the bacterium Xanthomonas campestris, is largely used in GF breadmaking, because it can hydrate in cold water and produce a viscous solution with strong shear-thinning flow behaviour (Diekjürgen \& Grainger, 2017; Peressini,

\footnotetext{
* Corresponding author.

E-mail address: ubarron@ipb.pt (U. Gonzales-Barron).
} 
Pin, \& Sensidoni, 2011). In low amounts, XG has been found to increase loaf volume, and improve bread rheological and sensory properties (Hager \& Arendt, 2013). The addition of xanthan gum in a food matrix contributes to obtain stable protein-based foams, with rheological properties typical for viscoelastic solids (Li \& Nie, 2016). By optimising textural and sensory attributes, researchers have recommended doses of XG in GF bread, that, in general, range between $0.5 \%$ up to $2.0 \%$ (flour weight); yet, this is strongly linked to bread formulation and water content (Hager \& Arendt, 2013; Sciarini, Ribotta, León, \& Pérez, 2010a).

As quinoa flour has a high level of non-heminic iron, its incorporation into GF products is nutritionally beneficial. According to Hager (Hager, 2013), the consumption of $100 \mathrm{~g}$ quinoa flour contributes $67 \%$ of the male and $30 \%$ of the female adult general population recommended dietary allowances (iron RDA) despite of the phytate content, which has a high chelating activity that may decrease bioavalailability of minerals such as iron;. Furthermore, quinoa flour is rich in sugars (glucose and fructose related with low glycemic index), dietary fibre, omega- 3 fatty acids and polyphenolic compounds, mainly phenolic acids and flavonoids (Pellegrini et al., 2018), indicating the way for its use as functional ingredient (in terms of antioxidant activity and control diseases) in breadmaking.

GF bread is commonly formulated with rice and maize flour since they are relatively cheap ingredients (Hager et al., 2012; Hager \& Arendt, 2013). Rice flour is usually preferred because of its colorlessness, nutritional characteristics, mild taste, low hypoallergenic properties (Renzetti \& Rosell, 2016), low levels of sodium and easy digestibility (Cornejo \& Rosell, 2015). Rice proteins have relatively poor functional properties, yet they can be enhanced in combination with quinoa proteins in breadmaking. Maize flour also contributes to gluten free breadmaking since their dietary fibre has been found to produce higher loaf volumeand lower crumb hardness as compared to GF bread without coarse maize flour (Naqash, Gani, Gani, \& Masoodi, 2017).

The objectives of this study were (i) to assess the combined effect of xanthan and water on the rheological properties of batter, and the physicochemical and textural properties of GF bread formulated with a mixture of rice, maize and quinoa flours; and (ii) to get an insight into the relationships among all the batter/bread quality attributes measured.

\section{Materials and methods}

\subsection{Breadmaking process}

Quinoa flour was obtained from a commercial mixture of saponinfree white quinoa varieties: Salcedo INIA, Kancolla, Pasankalla and Juli (grains mixture composition: $10.1 \%$ moisture, $13.6 \%$ protein, $3.2 \%$ crude fat, $3.1 \%$ ashes and $70 \%$ carbohydrates, particle size $\sim 1 \mathrm{~mm}$ ). Quinoa grains were milled in a laboratory disc mill (Faema, Spain), and then sieved through a rotating sifter. The quinoa flour had a particle size $<315 \mu \mathrm{m}$ measured using a test sieve (Retsch, Germany) and a vibratory sieve shaker (Retsch AS200 basic, Germany). Whole quinoa flour $(8.8 \%$ moisture, $12.9 \%$ protein, $5.0 \%$ fat, $2.2 \%$ ashes and $71.1 \%$ carbohydrates) was kept in polyethylene containers and maintained at room temperature $\left(\sim 20^{\circ} \mathrm{C}\right)$ conditions during its use.

GF breads were elaborated with rice flour (10.4\% moisture, $7.6 \%$ protein, $0.7 \%$ fat and $78.5 \%$ carbohydrates, particle size $<180 \mu \mathrm{m}$ ), maize flour $(11.5 \%$ moisture, $5.4 \%$ protein, $2.1 \%$ fat and $78.3 \%$ carbohydrates, particle size $<180 \mu \mathrm{m}$ ), sunflower oil, white sugar and refined salt purchased from a local supermarket (Bragança, Portugal). Instant yeast (Instaferm Lallemand, EU) and XG (E415) were provided by TecPan (Mirandela, Portugal). All batches were produced using a base formulation - established on trial-and-error experiments - of rice flour (50\%), maize flour (30\%) and quinoa flour (20\%), to which sunflower oil ( $6 \%$ flour weight), white sugar ( $3 \%$ flour weight), salt
(1.5\% flour weight), instant yeast (3\% flour weight), XG (1.5, 2.5 or $3.5 \%$ flour weight) and water (90, 100 or $110 \%$ flour weight) were added following a standardised procedure. Demineralised water $(\mathrm{pH}=6.8)$ kept at $5{ }^{\circ} \mathrm{C}$ overnight was used. The instant yeast (Saccharomyces cerevisiae lyophilized) was rehydrated and activated at $30{ }^{\circ} \mathrm{C}$ and $85 \%$ of relative humidity (RH) for $15 \mathrm{~min}$ in a chamber. After mixing dry ingredients for $2 \mathrm{~min}$ at speed 1 , liquid ingredients were added and mixed for an additional 5 min at speed 4, in a professional food processor (SilverCrest SKMP-1200, Germany) equipped with a batter blade.

Portions of $\sim 280 \mathrm{~g}$ were then poured into oiled and floured 520 -ml capacity tin moulds, and allowed to proof at $30^{\circ} \mathrm{C}$ and $85 \%$ of relative humidity for $60 \mathrm{~min}$ in a climatic chamber (Climacell 222, Germany). Afterwards, all moulds from the same batch were placed in a pre-heated convection oven (Princess, $2000 \mathrm{~W}$, The Netherlands) for $60 \mathrm{~min}$ at $190^{\circ} \mathrm{C}$. Bread loaves were un-moulded after $2 \mathrm{~h}$. All analyses were performed after $24 \mathrm{~h}$. All batter and crumb rheology parameters were determined using a texture analyzer TA-XT plus implemented with the Exponent software version 6.1.11.0 (Stable Micro Systems, UK). For calibration, a 5-kg load cell for stickiness analysis and a 30-kg load cell for back-extrusion and TPA analyses were used.

\subsection{Rheological properties of GF batter}

For analysis of the rheological properties of batter, $\sim 175 \mathrm{~g}$ was used. For the batter stickiness analysis, $\sim 5 \mathrm{~g}$ batter was weighed in a SMS/Chen-Hoseney stickiness cell (A/DSC) screwed to a SMS/ChenHoseney stickiness rig (Devi, Kavitake, \& Shetty, 2016); and then examined by the texture analyzer using a $25-\mathrm{mm}$ perspex cylinder probe $(\mathrm{P} / 25 \mathrm{P})$, while parameters were set at: pre-test speed $0.5 \mathrm{~mm} / \mathrm{s}$, test speed $0.5 \mathrm{~mm} / \mathrm{s}$ and post-test speed $10 \mathrm{~mm} / \mathrm{s}$, trigger force $5 \mathrm{~g}$, applied force $40 \mathrm{~g}$, contact time $0.1 \mathrm{~s}$ and return $4 \mathrm{~mm}$. After rotating the cell screw once to extrude a 1-mm-high batter sample, the perspex cap was placed over the exposed sample surface to minimize moisture loss, whilst allowing the batter surface to rest for $30 \mathrm{~s}$ to release the stress produced by extrusion (Ghodke, 2009). Ten repetitions were done for each GF batter formulation. Three stickiness analysis parameters were obtained: batter stickiness (STIba, in g), work of adhesion (ADHba, in $\mathrm{g} \cdot \mathrm{s}$ ), and batter cohesive-strength (SCOba, in $\mathrm{mm}$ ) (Agrahar-Murugkar, Gulati, Kotwaliwale, \& Gupta, 2015; Ghodke, 2009).

The back-extrusion analysis was performed using a $35 \mathrm{~mm}$-diameter perspex flat probe (model A/BE), a standard size back-extrusion cylindrical container ( $50 \mathrm{~mm}$-diameter, capacity of $\sim 115 \mathrm{~g}$ ) and a backward extrusion rig (model A/BE). The container was filled with $\sim 85 \mathrm{~g}$ of batter (75\% full). The settings of the assessment were: pre-test speed $1 \mathrm{~mm} / \mathrm{s}$, test speed $2 \mathrm{~mm} / \mathrm{s}$ and post-test speed $2 \mathrm{~mm} / \mathrm{s}$, trigger force $10 \mathrm{~g}$, penetrated to a depth of $15 \mathrm{~mm}$ and then returned to starting position (Devi, Kavitake, \& Shetty, 2016; Juszczak et al., 2012). Four repetitions were tested from each batch of GF batter. Several back-extrusion parameters were obtained: firmness (FIRba, in g), consistency (CONba, in g.s), cohesiveness (COHba, in g), and viscosity index (VISba, in $g \cdot s)$. Since COHba and VISba are calculated from the negative region of the back-extrusion profile curve, the higher the negative values, the more cohesive and viscous the batter, respectively.

\subsection{Physicochemical bread quality properties}

\subsubsection{Loaf specific volume and baking loss}

The GF loaf volume (ml) was determined using a modified standard rapeseed displacement method 10-05 (AACC International, 2000), using quinoa seeds instead of rapeseeds. The mould used to do the measurement was a parallelepiped with dimension of $10.4 \mathrm{~cm} \times 10.4 \mathrm{~cm} \times 7.5 \mathrm{~cm}$ (width $\times$ length $\times$ height). The loaf specific volume $(\mathrm{ml} / \mathrm{g})$ was calculated as loaf volume divided by loaf weight measured $24 \mathrm{~h}$ after baking (Sabanis \& Tzia, 2011). Baking loss was computed as [initial loaf weight before baking - the loaf weight 

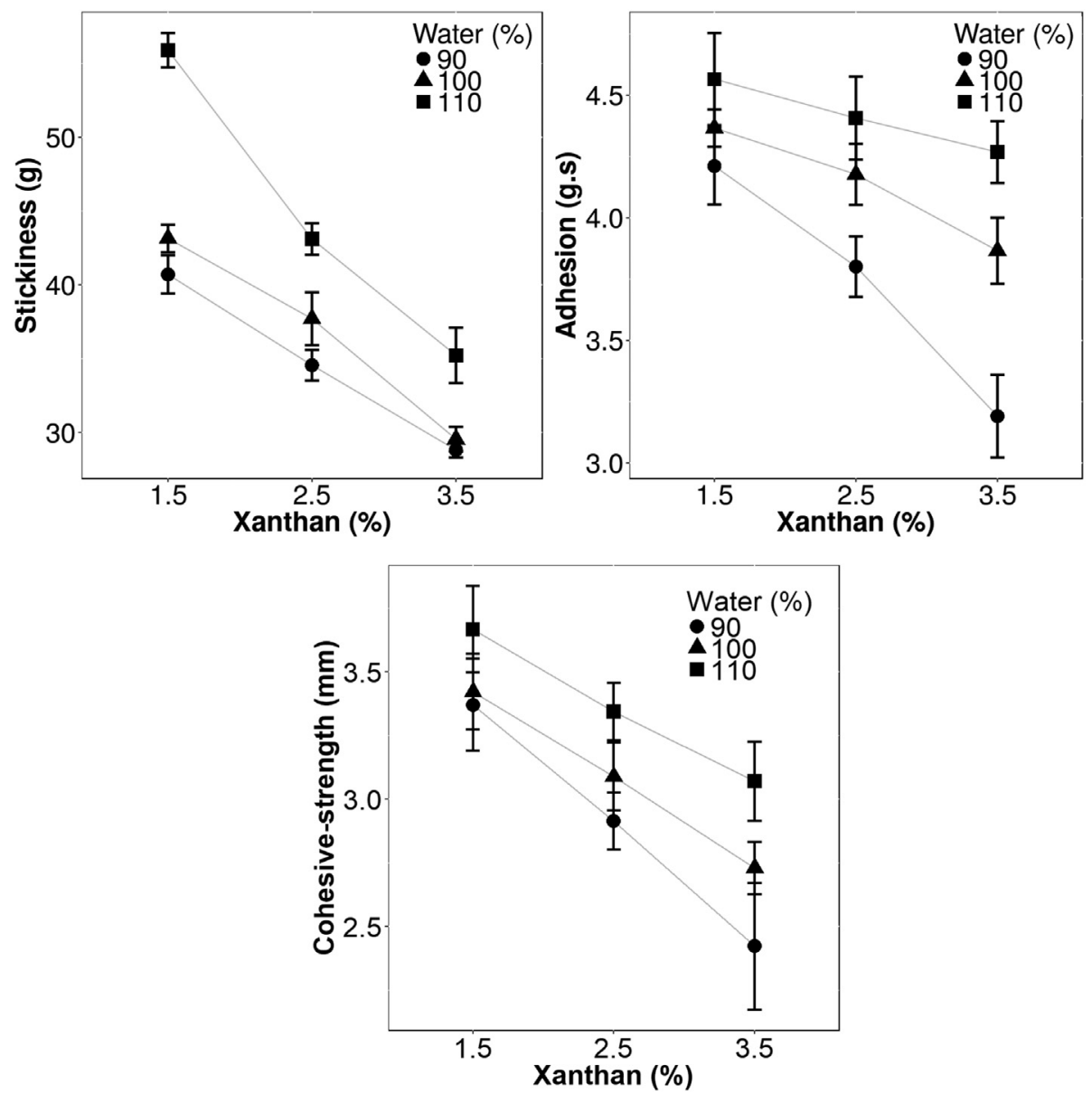

Fig. 1. Effect of xanthan gum and water content on the gluten-free batter stickiness properties of STIba (top left), ADHba (top right) and SCOba (bottom).

after $24 \mathrm{~h}$ baking $\times 100$ ]/initial loaf weight before baking (Bhatt \& Gupta, 2015; Turkut, Cakmak, Kumcuoglu, \& Tavman, 2016).

\subsubsection{Water activity and $p H$}

Water activity $\left(\mathrm{a}_{\mathrm{w}}\right)$ of the bread crumb was determined according to Machado-Alencar et al. (Machado-Alencar, Steel, Alvim, Carvalho de Morais, \& Andre-Bolini, 2015), measured at $20^{\circ} \mathrm{C}$ using an AquaLab (4TE Decagon, USA). Measurements were taken from four central slices from each loaf. Then, $\mathrm{pH}$ was measured according to Bhatt \& Gupta (Bhatt \& Gupta, 2015).

\subsection{Rheological properties of GF bread crumb}

The characterisation of the textural properties of bread crumb was carried out by means of the texture profile analysis (TPA). The GF loaves were sliced using an electric slicer (Bosch MAS4000W, Germany) to obtain 20-mm thickness. The two extreme slices of each loaf were discarded, and cylindrical crumb samples of $30 \mathrm{~mm}$-diameter were cut off from the centre of each slice. Four repetitions were performed. For the TPA, a $36 \mathrm{~mm}$-diameter aluminium probe (model P/36R) was used. The analysis was run at: pre-test speed $1 \mathrm{~mm} / \mathrm{s}$, test speed $2 \mathrm{~mm} / \mathrm{s}$ and post-test speed $2 \mathrm{~mm} / \mathrm{s}$, trigger force $5 \mathrm{~g}, 50 \%$ sample deformation (strain) and double compression (with a gap of $30 \mathrm{~s}$ between the two cycles). The TPA parameters obtained were: hardness (HARbr, in g), adhesiveness (ADHbr, in $\mathrm{g} \cdot \mathrm{s}$ ), springiness (SPRbr, dimensionless), cohesiveness (COHbr, dimensionless), resilience (RESbr, dimensionless), and chewiness (CHEbr, in g) (Martínez \& Gómez, 2017; Rinaldi, Paciulli, Caligiani, Scazzina, \& Chiavaro, 2017).

\subsection{Bread crumb image analysis}

Slices of bread were scanned (Canon Pixma MG-2550, Vietnam) using the IJ Scan Utility software (version 2.0.12, Canon, Japan) in grey level at $-10 \%$ brightness, $+15 \%$ contrast and 350 dpi resolution. Using the ImageJ software (v.1.51j8, Wayne Rasband, National Institute of Health, USA), the centre of the image was cropped into a $3.8 \mathrm{~cm} \times 3.8 \mathrm{~cm}$ field-of-view (with a spatial resolution of $1 \mathrm{~cm}=138$ pixels); and saved without any image compression in TIF format for posterior analysis. For each formulation, 32 images (4 loaves $\times 4$ slices $\times 2$ sides of the crumb) were acquired. Several grain crumb features were computed using the binary segmentation procedure based on the k-means clustering algorithm, proposed in Gonzales-Barron \& Butler (Gonzales-Barron \& Butler, 2006) and Gonzales-Barron \& Butler (Gonzales-Barron \& Butler, 2008), and were coded in Matlab software (ver. R2015a, The Mathworks, USA). These were: mean cell area (MCA, $\mathrm{mm}^{2}$ ); mean cell density (CDE, cells $/ \mathrm{mm}^{2}$ ); cell size uniformity (UNI, dimensionless), calculated as the rate between the number of cells $\leq 5 \mathrm{~mm}^{2}$ and number of cells $>5 \mathrm{~mm}^{2}$; void fraction (VFR, dimensionless), calculated as the proportion of the two-dimensional space occupied by the cells; mean cell compactness (COM, dimensionless), with compactness defined as the ratio of the cell area of a circle having the same perimeter; and mean cell aspect ratio (ARA, dimensionless), with aspect ratio defined as the ratio of the major axis to the minor axis of a cell.

\subsection{Statistical analyses}

The effects of XG (three doses tested: 1.5, 2.5 or 3.5\%) and WC (three levels tested: 90, 100 or 110\%) were evaluated using a full 
factorial design; thus, producing nine batches of GF bread. Analyses of variance were applied to assess the effect of XG, WC and their interaction on the response variables: baking loss, $\mathrm{pH}, \mathrm{a}_{\mathrm{w}}$, batter stickiness and back-extrusion, performed by a linear model. For the response variables: specific volume, TPA and bread crumb image features, a linear mixed model, was fitted instead to assess the main effects of XG dose and WC, and their interaction, assuming that measurements taken from the same loaf were correlated.

All two models were tested for the normality of residuals using standard diagnostics to ensure that all dependent variables met the assumptions of normal distribution. When the effects were significant ( $\alpha=0.05$ ), Tukey's Honest Significant Difference test was performed. Additionally, Kenward-Roger correction was applied for reducing small sample bias (McNeish \& Harring, 2017). Statistical analyses were conducted using the packages "plyr", "ggplot2", "lme4" and "lmerTest" for the linear models; and the packages: "rmisc", "rcmdmisc", "plyr", "ggplot2", "car", "multcompView" and "lsmeans" for the linear mixed models implemented in the R software version 3.3.3 (R Core Team, 2017).

\section{Results and discussion}

\subsection{Rheological properties of GF batter}

Both, XG and WC affected the rheology of GF batter, as implied by the results of the batter stickiness (Fig. 1) and the back-extrusion (Fig. 2) properties. The batter stickiness properties of STIba, ADHba and SCOba, ranged from 28.81 to $55.90 \mathrm{~g}$, from 3.19 to $4.57 \mathrm{~g} \cdot \mathrm{s}$ and from 2.42 to $3.67 \mathrm{~mm}$, respectively. At a constant XG level, higher WC consistently ( $\mathrm{p}<.001$ ) increased the STIba, ADHba and SCOba measurements, while at a constant WC level, higher XG contents consistently $(\mathrm{p}<.001)$ decreased the stickiness properties (Fig. 1). According to the Table 1, GF batters with higher XG content were significantly less sticky, as demonstrated by the low values of STIba (31.2 g), ADHba (3.78 g.s) and SCOba $(2.74 \mathrm{~mm})$ for treatments with $3.5 \%$ XG, compared with $1.5 \%$ XG ( $46.6 \mathrm{~g}, 4.38 \mathrm{~g} \cdot \mathrm{s}$ and $3.49 \mathrm{~mm}$, respectively) and $2.5 \%$ XG (38.5 g, $4.13 \mathrm{~g} \cdot \mathrm{s}$ and $3.12 \mathrm{~mm}$, respectively). On the other hand, as expected, the treatments with $110 \%$ WC $(\mathrm{p}<.001)$ gave stickier batters $(44.7 \mathrm{~g}, 4.41 \mathrm{~g} \cdot \mathrm{s}$ and $3.36 \mathrm{~mm})$ than treatments with $90 \%(34.7 \mathrm{~g}, 3.73 \mathrm{~g} \cdot \mathrm{s}$ and $2.90 \mathrm{~mm}$, respectively) and $100 \%$ WC (36.8 g, $4.14 \mathrm{~g} \cdot s$ and $3.08 \mathrm{~mm}$, respectively). Han, Cho, Kang, \& Koh (Han, Cho, Kang, \& Koh, 2012), working with rice flours, reported that the flour's water absorption has an effect on batter stickiness for high water absorption reduces stickiness and produces stiff batters.

The treatments of GF bread produced batters of variable viscosity. The back extrusion analysis values ranged for FIRba from 359 to $1990 \mathrm{~g}$, for CONba from 3494 to $17,363 \mathrm{~g} \cdot \mathrm{s}$, for COHba from -261 to $-1099 \mathrm{~g}$ and for VISba from -1250 to $-4692 \mathrm{~g} \cdot \mathrm{s}$. Higher (3.5\%) XG contents increased $(\mathrm{p}<.001)$ FIRba $(1434 \mathrm{~g})$, CONba $(13,076 \mathrm{~g} \cdot \mathrm{s})$, COHba $(-853 \mathrm{~g})$ and VISba $(-3566 \mathrm{~g} \cdot \mathrm{s})$ of batters compared to results obtained from treatments with $1.5 \%$ XG $(563 \mathrm{~g}, 5357 \mathrm{~g} \cdot \mathrm{s},-400 \mathrm{~g}$, $-1566 \mathrm{~g} \cdot \mathrm{s}$, respectively) and $2.5 \% \mathrm{XG}(1023 \mathrm{~g}, 9377 \mathrm{~g} \cdot \mathrm{s},-653 \mathrm{~g}$, -2735 g.s, respectively) (Table 2). On the other hand, higher (110\%) water levels had an opposite effect, reducing ( $\mathrm{p}<.001$ ) FIRba $(684 \mathrm{~g})$, CONba (6321 g.s), COHba $(-456 \mathrm{~g})$ and VISba $(-1971 \mathrm{~g} \cdot \mathrm{s})$ of batters. Using the same level of water (110\%), Sciarini et al. (Sciarini, Ribotta, León, \& Pérez, 2010b) obtained lower batter firmness values, from 50.8 to $1252 \mathrm{~g}$, for a mixture of corn/soy $(90: 10)$ and rice/soy $(80: 20)$,
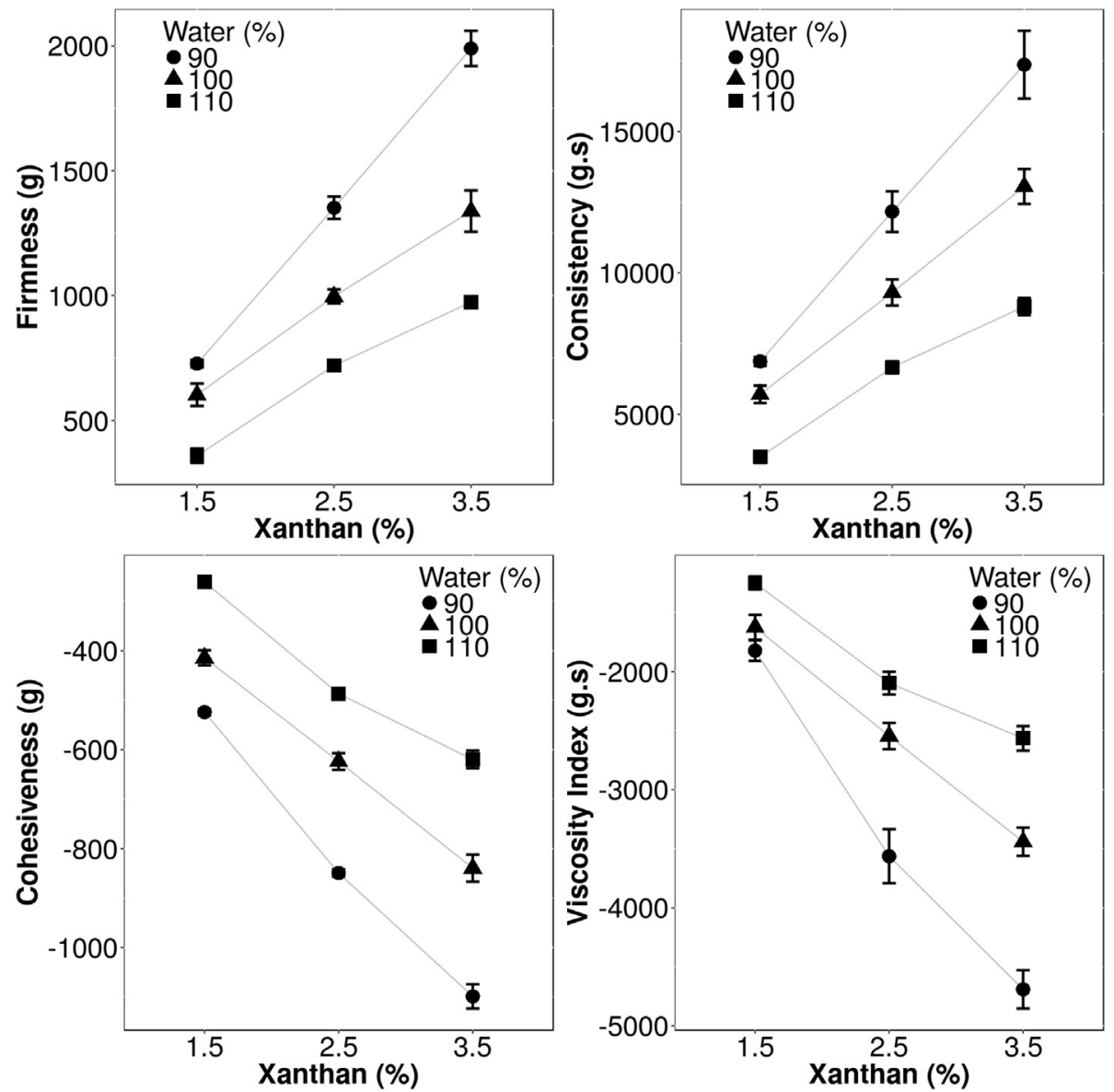

Fig. 2. Effect of xanthan gum and water content on the gluten-free batter back-extrusion properties of FIRba (top left), CONba (top right), COHba (bottom left) and VISba (bottom right). 
Table 1

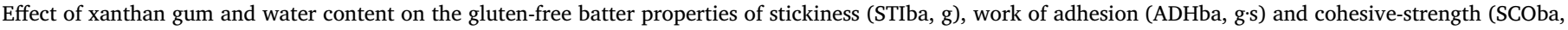
$\mathrm{mm})$.

\begin{tabular}{|c|c|c|c|c|c|c|c|c|c|c|}
\hline \multirow[t]{2}{*}{ Effects } & \multirow[t]{2}{*}{$\mathrm{N}^{*}$} & \multicolumn{3}{|c|}{ Stickiness (g) } & \multicolumn{3}{|c|}{ Work of adhesion $(\mathrm{g} \cdot \mathrm{s})$} & \multicolumn{3}{|c|}{ Cohesive-strength (mm) } \\
\hline & & Mean & $95 \% \mathrm{CI}$ & $\operatorname{Pr}(>\mathrm{F})$ & Mean & $95 \% \mathrm{CI}$ & $\operatorname{Pr}(>\mathrm{F})$ & Mean & $95 \% \mathrm{CI}$ & $\operatorname{Pr}(>F)$ \\
\hline Xanthan (\%) & & & & $<0.001$ & & & $<0.001$ & & & $<0.001$ \\
\hline 1.5 & 10 & $46.6^{\mathrm{a}}$ & {$[46.1-47.0]$} & & $4.38^{\mathrm{a}}$ & [4.33-4.43] & & $3.49^{\mathrm{a}}$ & [3.43-3.54] & \\
\hline 2.5 & 10 & $38.5^{\mathrm{b}}$ & [38.0-38.9] & & $4.13^{\mathrm{b}}$ & [4.08-4.18] & & $3.12^{\mathrm{b}}$ & [3.06-3.17] & \\
\hline 3.5 & 10 & $31.2^{\mathrm{c}}$ & [30.7-31.6] & & $3.78^{\mathrm{c}}$ & [3.72-3.83] & & $2.74^{\mathrm{c}}$ & [2.68-2.80] & \\
\hline Water (\%) & & & & $<0.001$ & & & $<0.001$ & & & $<0.001$ \\
\hline 90 & 10 & $34.7^{\mathrm{c}}$ & {$[34.2-35.1]$} & & $3.73^{\mathrm{c}}$ & [3.68-3.79] & & $2.90^{\mathrm{c}}$ & {$[2.85-2.96]$} & \\
\hline 100 & 10 & $36.8^{\mathrm{b}}$ & [36.4-37.2] & & $4.14^{\mathrm{b}}$ & [4.09-4.19] & & $3.08^{\mathrm{b}}$ & [3.02-3.14] & \\
\hline 110 & 10 & $44.7^{\mathrm{a}}$ & [44.3-45.2] & & $4.41^{\mathrm{a}}$ & [4.36-4.47] & & $3.36^{\mathrm{a}}$ & [3.30-3.42] & \\
\hline Interaction & & & & $<0.001$ & & & $<0.001$ & & & $<0.001$ \\
\hline
\end{tabular}

a,b,c Different letters indicate significant differences ( $\mathrm{p} \leq 0.05$ ).

* $\mathrm{N}$ refers to the total number of batter portions for analysis.

respectively. They concluded that rice/soy mixtures required higher force to extrude, because soy proteins have the ability to absorb cold water, resulting in a decrease of free water in the batter mixture. In this case, quinoa proteins, although different in composition, may have lent a greater cold water absorption capability, hence producing batters of higher firmness than those with soy proteins. Quinoa's $11 \mathrm{~S}$ globulin, also referred to as chenopodin, has a similar structure to glycinin, the 11S globulin of soy (Ruiz, Xiao, van Boekel, Minor, \& Stieger, 2016). In general, 11S type globulins from pseudocereals have predominantly $\beta$ sheet structure with $\beta$-barrel conformation and, therefore they are associated in the formation of good quality batters (Mir, Riar, \& Singh, 2018).

All of the batter properties presented significant interaction between WC and XG (Tables 1 and 2), which can be visualised in Figs. 1 and 2, whereby the effect of water on batter rheology was more discernible at higher XG doses than at lower ones. For instance, for back extrusion viscosity index, at a constant WC of $110 \%$, the increase in XG from 1.5 to $3.5 \%$, increased batter viscosity index by $\sim 100 \%$ while, at the lowest WC of $90 \%$, the increase was higher at $\sim 160 \%$. Therefore, formulating bread with higher doses of XG may bring about greater variations in texture quality, if WC is not optimized. According to Diekjürgen \& Grainger (Diekjürgen \& Grainger, 2017), this phenomenon is an effect of the polyanionic behaviour of xanthan gum due to the acetic and pyruvic acid groups of its chemical structure. These acid groups influence the GF batter properties, allowing more interactions with water through hydrogen bonds. Moreover, negatively-charged hydrocolloids (xanthan gum) are more prone to build intermolecular hydrogen bonds with water (Horstmann, Axel, \& Arendt, 2018). Funami et al. (Funami et al., 2005) and Horstmann et al. (Horstmann, Axel, \& Arendt, 2018) explained the link between a high number of branches of XG and increased interactions with water. The higher the molecular weight, the greater the water holding capacity due to the higher radius of gyration (i.e., water around the hydrocolloid).

Comparing between 1.5 and $2.5 \%$ of XG in a GF fresh pasta batter, Sanguinetti et al. (Sanguinetti et al., 2015) observed that a higher amount of XG resulted in a more cohesive, less adhesive and more elastic batter. Sabanis \& Tzia (Sabanis \& Tzia, 2011) and Turkut et al. (Turkut, Cakmak, Kumcuoglu, \& Tavman, 2016) reported that higher consistency values and viscosity index in their GB batter led to lower specific volume. This finding was corroborated in the present study, where $3.5 \%$ XG dose produced loaves of lower specific volume (1.69 ml/g; Table 3) compared to those obtained from treatments with 1.5\% XG (1.78 ml/g; Fig. 3).

\subsection{Physicochemical properties of GF bread}

The specific volume, baking loss, $\mathrm{pH}$ and $\mathrm{a}_{\mathrm{w}}$ values of GF breads are summarized in Table 3, while side photographs of loaves produced varying XG and WC are displayed at Fig. 3.

Table 2

Effect of xanthan gum and water content on the gluten-free back-extrusion properties of firmness (FIRba, g), consistency (CONba, g·s), cohesiveness (COHba, g) and viscosity index (VISba, g:s).

\begin{tabular}{|c|c|c|c|c|c|c|c|c|c|c|c|c|c|}
\hline \multirow[t]{2}{*}{ Effects } & \multirow[t]{2}{*}{$\mathrm{N}^{*}$} & \multicolumn{3}{|c|}{ Firmness (g) } & \multicolumn{3}{|c|}{ Consistency $(\mathrm{g} \cdot \mathrm{s})$} & \multicolumn{3}{|c|}{ Cohesiveness (g) } & \multicolumn{3}{|c|}{ Viscosity index $(\mathrm{g} \cdot \mathrm{s})$} \\
\hline & & Mean & $95 \% \mathrm{CI}$ & $\operatorname{Pr}(>F)$ & Mean & $95 \% \mathrm{CI}$ & $\operatorname{Pr}(>F)$ & Mean & $95 \% \mathrm{CI}$ & $\operatorname{Pr}(>F)$ & Mean & $95 \% \mathrm{CI}$ & $\operatorname{Pr}(>F)$ \\
\hline Xanthan (\%) & & & & $<0.001$ & & & $<0.001$ & & & $<0.001$ & & & $<0.001$ \\
\hline 1.5 & 4 & $563^{c}$ & [537-590] & & $5357^{c}$ & [5024-5690] & & $-399.7^{\mathrm{c}}$ & $\begin{array}{l}{[-389.7 \text { to }} \\
-409.7]\end{array}$ & & $-1566^{c}$ & $\begin{array}{l}{[-1490 \text { to }} \\
-1642]\end{array}$ & \\
\hline 2.5 & 4 & $1023^{b}$ & [996-1049] & & $9377^{\mathrm{b}}$ & [9044-9710] & & $-653.4^{b}$ & $\begin{array}{l}{[-643.4 \text { to }} \\
-663.4]\end{array}$ & & $-2735^{b}$ & $\begin{array}{l}{[-2660 \text { to }} \\
-2811]\end{array}$ & \\
\hline 3.5 & 4 & $1434^{\mathrm{a}}$ & [1408-1461] & & $13076^{\mathrm{a}}$ & {$[12742-13,408]$} & & $-852.7^{\mathrm{a}}$ & $\begin{array}{l}{[-842.7 \text { to }} \\
-862.6]\end{array}$ & & $-3566^{a}$ & {$[-3490--3642]$} & \\
\hline Water (\%) & & & & $<0.001$ & & & $<0.001$ & & & $<0.001$ & & & $<0.001$ \\
\hline 90 & 4 & $1356^{\mathrm{a}}$ & [1330-1383] & & $12133^{\mathrm{a}}$ & [11801-12,466] & & $-824.2^{\mathrm{a}}$ & $\begin{array}{l}{[-814.2 \text { to }} \\
-834.2]\end{array}$ & & $-3359^{a}$ & $\begin{array}{l}{[-3283 \text { to }} \\
-3435]\end{array}$ & \\
\hline 100 & 4 & $980^{\mathrm{b}}$ & [953-1006] & & $9355^{\mathrm{b}}$ & [9023-9688] & & $-625.8^{b}$ & $\begin{array}{l}{[-615.8 \text { to }} \\
-635.8]\end{array}$ & & $-2537^{\mathrm{b}}$ & $\begin{array}{l}{[-2461 \text { to }} \\
-2613]\end{array}$ & \\
\hline 110 & 4 & $684^{c}$ & [658-711] & & $6321^{c}$ & [5988-6654] & & $-455.8^{c}$ & $\begin{array}{l}{[-445.8 \text { to }} \\
-465.8]\end{array}$ & & $-1971^{c}$ & $\begin{array}{l}{[-1895 \text { to }} \\
-2047]\end{array}$ & \\
\hline Interaction & & & & $<0.001$ & & & $<0.001$ & & & $<0.001$ & & & 0.04 \\
\hline
\end{tabular}

a,b,c Different letters indicate significant differences ( $\mathrm{p} \leq 0.05$ ).

${ }^{*} \mathrm{~N}$ refers to the total number of batter portions for analysis. 
Table 3

Effect of xanthan gum and water content on the gluten-free bread physicochemical properties of specific volume (ml/g), baking loss (\%), pH and $\mathrm{a}_{\mathrm{w}}$.

\begin{tabular}{|c|c|c|c|c|c|c|c|c|c|c|c|c|c|}
\hline \multirow[t]{2}{*}{ Effects } & \multirow[t]{2}{*}{$\mathrm{N}^{*}$} & \multicolumn{3}{|c|}{ Specific volume $(\mathrm{ml} / \mathrm{g})$} & \multicolumn{3}{|c|}{ Baking loss (\%) } & \multicolumn{3}{|l|}{$\mathrm{pH}$} & \multicolumn{3}{|l|}{$a_{w}$} \\
\hline & & Mean & $95 \% \mathrm{CI}$ & $\operatorname{Pr}(>F)$ & Mean & $95 \% \mathrm{CI}$ & $\operatorname{Pr}(>F)$ & Mean & $95 \% \mathrm{CI}$ & $\operatorname{Pr}(>F)$ & Mean & $95 \% \mathrm{CI}$ & $\operatorname{Pr}(>F)$ \\
\hline Xanthan (\%) & & & & $<0.001$ & & & $<0.001$ & & & $<0.001$ & & & $<0.001$ \\
\hline 1.5 & 4 & $1.78^{\mathrm{a}}$ & [1.78-1.79] & & $13.5^{\mathrm{a}}$ & [13.4-13.6] & & $6.610^{\mathrm{a}}$ & [6.606-6.615] & & $0.9806^{\mathrm{a}}$ & [0.9805-0.9807] & \\
\hline 2.5 & 4 & $1.73^{\mathrm{b}}$ & [1.73-1.74] & & $13.1^{\mathrm{b}}$ & [13.0-13.1] & & $6.569^{\mathrm{b}}$ & [6.564-6.573] & & $0.9796^{\mathrm{b}}$ & [0.9795-0.9797] & \\
\hline 3.5 & 4 & $1.69^{c}$ & [1.69-1.70] & & $12.7^{\mathrm{c}}$ & [12.7-12.8] & & $6.520^{c}$ & [6.515-6.524] & & $0.9785^{c}$ & [0.9784-0.9786] & \\
\hline Water (\%) & & & & $<0.001$ & & & $<0.001$ & & & $<0.001$ & & & $<0.001$ \\
\hline 90 & 4 & $1.63^{\mathrm{c}}$ & [1.62-1.63] & & $12.0^{\mathrm{c}}$ & [11.9-12.1] & & $6.546^{\mathrm{c}}$ & [6.542-6.546] & & $0.9778^{c}$ & [0.9777-0.9779] & \\
\hline 100 & 4 & $1.73^{\mathrm{b}}$ & [1.72-1.73] & & $13.2^{\mathrm{b}}$ & [13.2-13.3] & & $6.565^{\mathrm{b}}$ & [6.561-6.570] & & $0.9796^{\mathrm{b}}$ & [0.9795-0.9798] & \\
\hline 110 & 4 & $1.86^{\mathrm{a}}$ & [1.85-1.86] & & $14.0^{\mathrm{a}}$ & [14.0-14.1] & & $6.588^{\mathrm{a}}$ & [6.583-6.592] & & $0.9813^{\mathrm{a}}$ & [0.9811-0.9814] & \\
\hline Interaction & & & & 0.10 & & & $<0.001$ & & & 0.35 & & & $<0.001$ \\
\hline
\end{tabular}

a,b,c Different letters indicate significant differences $(\mathrm{p} \leq 0.05)$.

* $\mathrm{N}$ refers to number of loaves.

\subsubsection{Loaf specific volume and baking loss}

Specific volume was affected $(\mathrm{p}<.001$ ) by xanthan and hydration; however, the interaction of both factors had no significant effect (Table 3). The specific volume of bread ranged from 1.58 to $1.91 \mathrm{ml} / \mathrm{g}$, decreasing $(\mathrm{p}<.001)$ with higher XG dose, and increasing ( $\mathrm{p}<.001)$ with higher WC. Values as high as $4-5 \mathrm{ml} / \mathrm{g}$ are usual for wheat breads, depending on the formulation, breadmaking method and the use or not of sourdough; however, values between 1.33 and $2.40 \mathrm{ml} / \mathrm{g}$ are expected for GF bread (Hager et al., 2012; Marti et al., 2017). Similarly, Burešová, Masaříková, Hřivna, Kulhanová, \& Bureš, (Burešová, Masař́k ková, Hřivna, Kulhanová, \& Bureš, 2016) obtained a loaf specific volume of $1.9 \mathrm{ml} / \mathrm{g}$ for rice-buckwheat blend and $2 \%$ of XG, while Sciarini et al. (Sciarini, Ribotta, León, \& Pérez, 2012) obtained a similar specific volume $(1.86 \mathrm{ml} / \mathrm{g})$ in a matrix of rice flour $(45 \%)$, cassava starch (45\%), soy flour (10\%), WC (75\%) and XG (0.5\%).

According to Hager et al. (Hager et al., 2012), one important parameter in GF breadmaking, known to strongly influence consumer's choice, is the loaf specific volume, as larger loaves are perceived as more appealing. Likewise, from an economic standpoint, a high ratio of volume per weight is also desirable for the producer. The positive impact of high WC was evident in the specific volume of GF breads, which can be explained by the plasticizer effect of water which contributes to the extensional properties of the batter during mixing allowing the hydration of the particles (de la Hera, Rosell, \& Gómez, 2014). Nonetheless, Han et al. (Han, Cho, Kang, \& Koh, 2012) reported that excessive water can be detrimental as it may cause overexpansion during baking resulting in collapsed loaves. Onyango, Mutungi, Unbehend, \& Lindhauer (Onyango, Mutungi, Unbehend, \& Lindhauer, 2011) explained that, as gas leaks out of the bubbles, it forces its way through the weakly connected particles and channels formed by gas pressing the particles apart. Since, in our experiments, small-sized bread loaves were mostly associated to lower baking losses; we can conclude that, regardless of the XG amount, batters with low WC tended to proof insufficiently, resulting in bread loaves of lower volume.

Moisture loss during baking ranged from 11.9 to $14.5 \%$, increasing ( $\mathrm{p}<.001)$ with higher WC, and decreasing $(\mathrm{p}<.001)$ with higher XG content (Table 3). However, although higher XG amounts reduce baking loss, it can negatively affect the volume of loaves (Fig. 3). Lower baking loss values (12.7\%) were obtained for 3.5\% XG formulations, compared to those obtained from formulations with 1.5\% XG (13.5\%) and $2.5 \%$ XG (13.1\%) (Table 3). On the other hand, there was a proportional relationship between added water and baking loss; namely, 90,100 and $110 \%$ of WC resulted in baking losses of 12.0, 13.2 and $14.0 \%$, respectively.

Turkut et al. (Turkut, Cakmak, Kumcuoglu, \& Tavman, 2016) obtained slighty higher baking loss values (from 15.1 to $15.4 \%$ ) in a

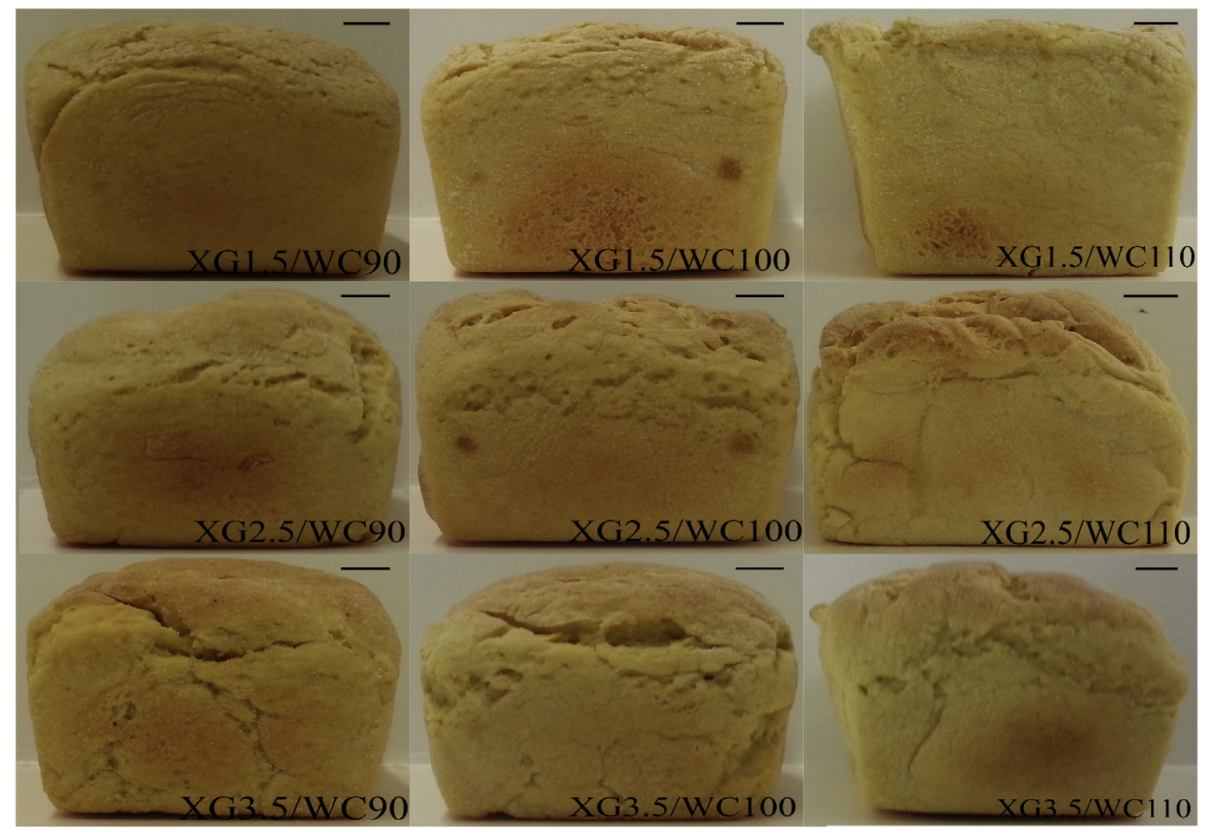

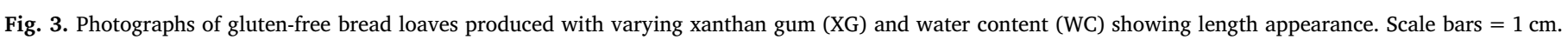


matrix of rice flour (25\%), potato starch (25\%), WC (87\%), XG $(0.5 \%)$, and varing quinoa flour (from 12.5 to $50 \%$ ) and buckwheat flour (from 37.5 to $0 \%$ ). As observed by Onyango et al. (Onyango, Mutungi, Unbehend, \& Lindhauer, 2011), formulations with high water contents gave mixtures that resembled batters, whereas those with low water contents gave batters that lacked elasticity. Breads made from batters containing high water contents had higher volumes than those made from batters containing low water content.

\subsubsection{Water activity $\left(a_{w}\right)$ and $p H$}

As expected, according to Table 3, the amount of free water in the crumb significantly decreased with the addition of higher concentrations of XG ( $p<.001)$ and lower WC amounts $(\mathrm{p}<.001)$.

Hager et al. (Hager et al., 2012) formulated GF breads with flours from different botanical sources, and obtained $\mathrm{a}_{\mathrm{w}}$ values of crumb ranging from 0.969 to 0.987 . Since microbial stability of GF breads could be compromised by high $\mathrm{a}_{\mathrm{w}}$, treatments with higher XG and lower WC amounts would be desired from the safety viewpoint. In relation the $\mathrm{pH}$ parameter, bread acidity was also influenced by the addition of XG $(\mathrm{p}<.001)$ and WC $(\mathrm{p}<.001)$, with more acidic crumbs produced by higher doses of XG. GF breads showed a pH from 6.50 to 6.64. Lower $\mathrm{pH}$ values (6.52) were obtained for treatments with $3.5 \% \mathrm{XG}$, compared with $\mathrm{pH}$ values obtained from treatments with $1.5 \% \mathrm{XG}$ (6.57) and $2.5 \%$ XG (6.61). On the other hand, 90,100 and $110 \%$ of WC resulted in slightly less acidic crumbs, with $\mathrm{pH}$ values of 6.55, 6.57 and 6.59, respectively.

\subsection{Rheological properties of GF bread crumb}

The parameters of the TPA (HARbr, ADHbr, SPRbr, COHbr and RESbr) were affected ( $p<0.01)$ by XG, WC and their interaction; however, XG had no significant effect on CHEbr (Table 4). Having produced firmer, more viscous and less sticky batters, lower WC levels consequently yielded tougher breads (Fig. 4). According to the TPA, loaves with the lowest WC $(90 \%)$ were significantly harder $($ HARbr $=5130 \mathrm{~g})$, more chewy $(\mathrm{CHEbr}=2031 \mathrm{~g})$, and less cohesive
$(\mathrm{COHbr}=0.477), \quad$ springy $\quad(\mathrm{SPRbr}=0.833) \quad$ and $\quad$ resilient $($ RESbr $=0.188)$ than the treatments with 100 and $110 \%$ WC. However, the addition of higher amounts of water can improve crumb texture, since the $110 \%$ WC treatments produced softer breads, with lower ( $\mathrm{p}<.001)$ values of HARbr $(1995 \mathrm{~g})$, ADHbr $(-12.80 \mathrm{~g} \cdot \mathrm{s})$, CHEbr (911 g), and higher values of SPRbr (0.884), COHbr (0.517) and RESbr (0.217), compared to those obtained from the lower WC treatments of 90 and $100 \%$. Although, to a lower extent than WC $\left(\mathrm{p}=2.2 \times 10^{-16}\right), \mathrm{XG}(\mathrm{p}=0.001)$ also had an impact on bread crumb texture. According to Cornejo \& Rosell (Cornejo \& Rosell, 2015), high springiness values are preferred because it is related to the bread freshness and elasticity, a reduction in resilience or springiness characterises loss of elasticity, because both properties indicate the ability of a material to return to its original shape after stressing. In our work, the highest springiness was reached at a XG dose of $2.5 \%$, and springiness and resilience increased with increasing WC (Fig. 4).

As reported by Onyango et al. (Onyango, Mutungi, Unbehend, \& Lindhauer, 2011), cohesiveness characterises the extent to which a material can be deformed before it ruptures; and reflects the internal cohesion of the material. Bread crumb with high cohesiveness is desirable because it forms a bolus, instead of disintegrating during mastication whereas low cohesiveness indicates increased susceptibility of the bread to fracture or crumble. In this study, GF bread with amounts of $3.5 \%$ XG and $110 \%$ WC attained the highest cohesiveness. Although not directly comparable with this study, Cornejo \& Rosell (Cornejo \& Rosell, 2015) obtained, for GF bread elaborated with different long grain rice flours, lower values for hardness (ranged from 361 to $1105 \mathrm{~g}$ ) and springiness (ranged from 0.68 to 0.80 ), and similar values for resilience (from 0.20 to 0.35 ), chewiness (from 914 to $2066 \mathrm{~g}$ ) and cohesiveness (from 0.44 to 0.67). Likewise, Onyango et al. (Onyango, Mutungi, Unbehend, \& Lindhauer, 2011) obtained, for GF bread elaborated with different rice, cassava, potato and maize starches-sorghum ratios, comparable TPA values for firmness (i.e., hardness) from 760 to $4862 \mathrm{~g}$ and chewiness (from 666 to $2383 \mathrm{~g}$ ), although they measured higher values for cohesiveness (from 0.563 to 0.756 ), springiness (from 0.875 to 0.997 ) and resilience (from 0.328 to 0.438 ). For a rice-

Table 4

Effect of xanthan gum and water content on the gluten-free bread instrumental textural profile analysis (TPA) properties of hardness (HARbr, g), adhesiveness (ADHbr, g.s), springiness (SPRbr, dimensionless), cohesiveness (COHbr, dimensionless), chewiness (CHEbr, g) and resilience (RESbr, dimensionless).

\begin{tabular}{|c|c|c|c|c|c|c|c|c|c|c|}
\hline \multirow[t]{2}{*}{ Effects } & \multirow[t]{2}{*}{$\mathrm{N}^{*}$} & \multicolumn{3}{|c|}{ Hardness (g) } & \multicolumn{3}{|c|}{ Adhesiveness $(\mathrm{g} \cdot \mathrm{s})$} & \multicolumn{3}{|c|}{ Springiness } \\
\hline & & Mean & $95 \% \mathrm{CI}$ & $\operatorname{Pr}(>F)$ & Mean & $95 \% \mathrm{CI}$ & $\operatorname{Pr}(>F)$ & Mean & $95 \% \mathrm{CI}$ & $\operatorname{Pr}(>F)$ \\
\hline Xanthan (\%) & & & & 0.001 & & & $<0.001$ & & & 0.001 \\
\hline 1.5 & 2 & $3574^{\mathrm{a}}$ & [3405-3742] & & $-9.1^{c}$ & {$[-6.5$ to -11.8$]$} & & $0.864^{\mathrm{a}}$ & {$[0.858-0.871]$} & \\
\hline 2.5 & 2 & $3355^{\mathrm{ab}}$ & [3186-3523] & & $-21.1^{\mathrm{b}}$ & {$[-18.4$ to -23.7$]$} & & $0.877^{\mathrm{a}}$ & {$[0.870-0.884]$} & \\
\hline 3.5 & 2 & $3175^{\mathrm{b}}$ & [3007-3344] & & $-40.6^{\mathrm{a}}$ & {$[-38.0$ to -43.3$]$} & & $0.837^{\mathrm{b}}$ & {$[0.831-0.844]$} & \\
\hline Water (\%) & & & & $<0.001$ & & & $<0.001$ & & & $<0.001$ \\
\hline 90 & 2 & $5130^{\mathrm{a}}$ & [4961-5298] & & $-25.8^{\mathrm{a}}$ & {$[-23.1$ to -29.6$]$} & & $0.833^{c}$ & [0.826-0.839] & \\
\hline 100 & 2 & $2980^{b}$ & [2811-3148] & & $-32.3^{\mathrm{a}}$ & {$[-28.4$ to -34.9$]$} & & $0.862^{\mathrm{b}}$ & [0.855-0.869] & \\
\hline 110 & 2 & $1995^{c}$ & [1826-2163] & & $-12.8^{\mathrm{b}}$ & {$[-10.1$ to -15.5$]$} & & $0.884^{\mathrm{a}}$ & [0.877-0.891] & \\
\hline Interaction & & & & 0.001 & & & $<0.001$ & & & $<0.001$ \\
\hline \multirow[t]{2}{*}{ Effects } & $\mathrm{N}^{*}$ & \multicolumn{3}{|c|}{ Cohesiveness } & \multicolumn{3}{|c|}{ Chewiness (g) } & \multicolumn{3}{|c|}{ Resilience } \\
\hline & & Mean & $95 \% \mathrm{CI}$ & $\operatorname{Pr}(>F)$ & Mean & $95 \% \mathrm{CI}$ & $\operatorname{Pr}(>F)$ & Mean & $95 \% \mathrm{CI}$ & $\operatorname{Pr}(>F)$ \\
\hline Xanthan (\%) & & & & $<0.001$ & & & 0.05 & & & 0.001 \\
\hline 1.5 & 2 & $0.453^{\mathrm{c}}$ & {$[0.445-0.461]$} & & $1353^{\mathrm{a}}$ & [1288-1419] & & $0.187^{\mathrm{b}}$ & [0.183-0.192] & \\
\hline 2.5 & 2 & $0.513^{\mathrm{b}}$ & [0.505-0.521] & & $1407^{\mathrm{a}}$ & [1341-1473] & & $0.213^{\mathrm{a}}$ & {$[0.208-0.218]$} & \\
\hline 3.5 & 2 & $0.532^{\mathrm{a}}$ & {$[0.523-0.540]$} & & $1461^{\mathrm{a}}$ & [1395-1527] & & $0.207^{\mathrm{a}}$ & {$[0.203-0.212]$} & \\
\hline Water (\%) & & & & 0.001 & & & $<0.0001$ & & & $<0.001$ \\
\hline 90 & 2 & $0.477^{\mathrm{b}}$ & [0.469-0.485] & & $2031^{\mathrm{a}}$ & [1965-2097] & & $0.188^{c}$ & [0.183-0.192] & \\
\hline 100 & 2 & $0.503^{\mathrm{a}}$ & [0.495-0.511] & & $1280^{\mathrm{b}}$ & [1214-1346] & & $0.203^{\mathrm{b}}$ & [0.199-0.208] & \\
\hline 110 & 2 & $0.517^{\mathrm{a}}$ & [0.509-0.525] & & $911^{c}$ & [845-977] & & $0.217^{\mathrm{a}}$ & {$[0.212-0.221]$} & \\
\hline Interaction & & & & $<0.001$ & & & 0.001 & & & $<0.001$ \\
\hline
\end{tabular}

a,b,c Different letters indicate significant differences ( $\mathrm{p} \leq 0.05$ ).

$* \mathrm{~N}$ refers to number of loaves. 

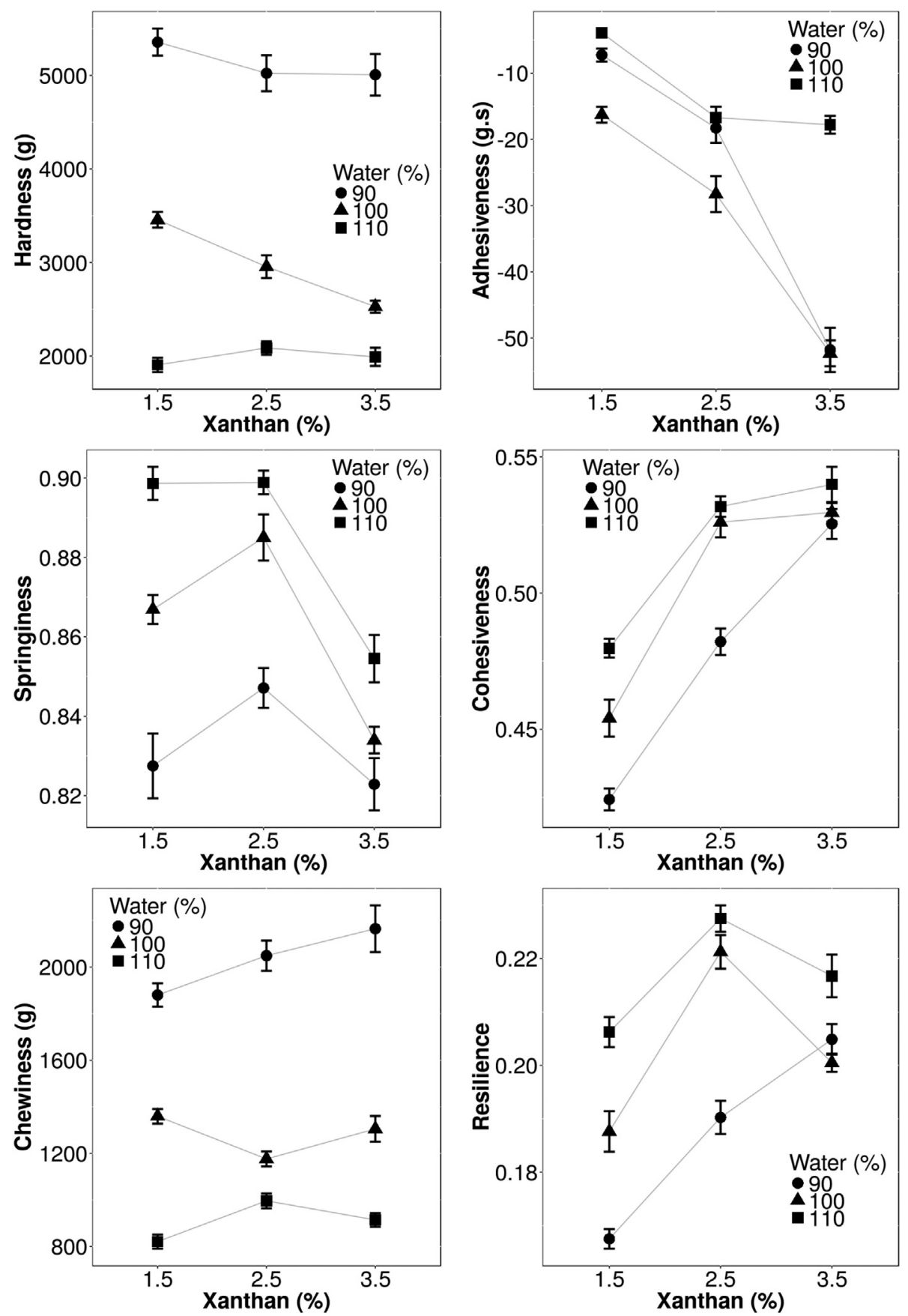

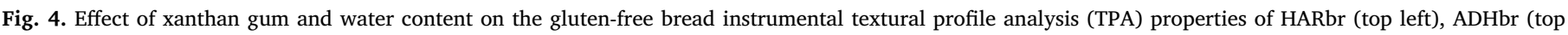
right), SPRbr (middle left), COHbr (middle right), CHEbr (bottom left) and RESbr (bottom right).

buckwheat blend with $2 \%$ of XG, Burešová et al. (Burešová, Masaříková, Hřivna, Kulhanová, \& Bureš, 2016) obtained softer bread (928 g), and higher cohesiveness (0.61) and chewiness $(11,830 \mathrm{~g} \cdot \mathrm{s})$.

\subsection{Image analysis features of crumb grain}

Digital images of GF crumb grain showed visual differences among the nine formulations (Fig. 5). Whereas higher WC formulations produced more open grain textures, lower WC formulations produced the opposite trend:closer crumbs of smaller pores. Such differences were statistically corroborated in all of the image grain features analyzed.

Higher doses of XG produced loaf slices of lower MCA, VFR and ARA values $(\mathrm{p}<.001)$, and higher CDE, UNI and COM $(\mathrm{p}<.001)$. At a constant level of water in the formulation, increasing XG doses only produces smaller bread loaves. These smaller loaves tend to have a close visual grain texture, formed of more cells of smaller size. As a consequence, the cell size uniformity is greater but the void fraction is lower. Smaller loaves of denser texture also present the characteristic of having more rounded cells (i.e., higher cell compactness and lower mean cell aspect ratio). Loaves of lower XG contents (1.5\%) exhibited crumbs made up of larger pores, with higher values of MCA $\left(1.35 \mathrm{~mm}^{2}\right)$, VFR (0.29) and ARA (1.75); and lower values of CDE $\left(0.25\right.$ cells $\left./ \mathrm{mm}^{2}\right)$, UNI (20.5) and COM (0.76) compared to those obtained with higher XG levels of 2.5 and 3.5\% (Table 5 and Fig. 6).

On the other hand, when higher proportions of WC (110\%) were added, the opposite was observed; this is, values of $\operatorname{CDE}(0.25$ cells/ $\mathrm{mm}^{2}$ ), UNI (17.5) and COM (0.758) were lower $(\mathrm{p}<.001)$, while values of MCA $\left(1.38 \mathrm{~mm}^{2}\right.$ ), VFR (0.30) and ARA (1.75) were higher 


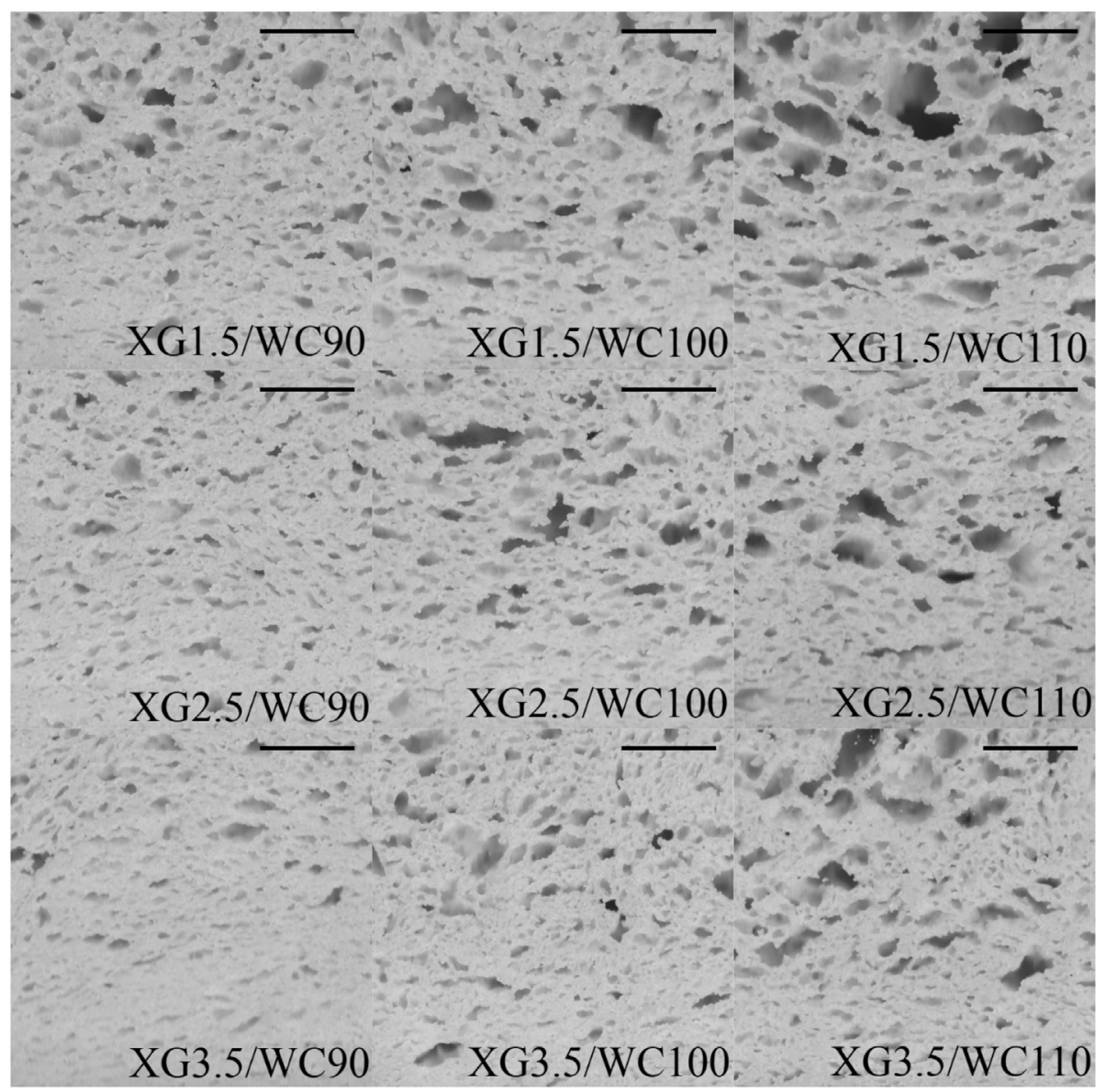

Fig. 5. Crumb grain of gluten-free bread produced by varying xanthan gum (XG) and water content (WC). Scale bars $=1 \mathrm{~cm}$.

Table 5

Effect of xanthan gum and water content on the gluten-free bread crumb grain features of mean cell area (MCA, $\left.\mathrm{mm}^{2}\right)$, mean cell density $\left(\mathrm{CDE}\right.$, cells/mm $\left.{ }^{2}\right)$, cell size uniformity (UNI, dimensionless), void fraction (VFR, dimensionless), mean cell compactness (COM, dimensionless), and mean cell aspect ratio (ARA, dimensionless).

\begin{tabular}{|c|c|c|c|c|c|c|c|c|c|c|}
\hline Effects & $\mathrm{N}^{*}$ & \multicolumn{3}{|c|}{ Mean cell area $\left(\mathrm{mm}^{2}\right)$} & \multicolumn{3}{|c|}{ Mean cell density (cells $/ \mathrm{mm}^{2}$ ) } & \multicolumn{3}{|c|}{ Cell size uniformity } \\
\hline Xanthan (\%) & & & & $<0.001$ & & & $<0.001$ & & & $<0.001$ \\
\hline 2.5 & 8 & $1.04^{\mathrm{b}}$ & [0.99-1.10] & & $0.285^{\mathrm{b}}$ & [0.276-0.294] & & $30.4^{\mathrm{b}}$ & [26.5-34.4] & \\
\hline 3.5 & 8 & $0.91^{\mathrm{c}}$ & {$[0.86-0.97]$} & & $0.306^{\mathrm{a}}$ & {$[0.298-0.315]$} & & $39.3^{\mathrm{a}}$ & [35.4-43.3] & \\
\hline Water (\%) & & & & $<0.001$ & & & $<0.001$ & & & $<0.001$ \\
\hline 90 & 8 & $0.83^{\mathrm{c}}$ & [0.77-0.88] & & $0.312^{\mathrm{a}}$ & [0.303-0.320] & & $48.4^{\mathrm{a}}$ & [44.4-52.4] & \\
\hline Interaction & & & & $<0.001$ & & & 0.006 & & & 0.08 \\
\hline \multirow[t]{2}{*}{ Effects } & \multirow[t]{2}{*}{$\mathrm{N}^{*}$} & \multicolumn{3}{|c|}{ Void fraction } & \multicolumn{3}{|c|}{ Mean cell compactness } & \multicolumn{3}{|c|}{ Mean cell aspect ratio } \\
\hline & & Mean & $95 \% \mathrm{CI}$ & $\operatorname{Pr}(>F)$ & Mean & $95 \% \mathrm{CI}$ & $\operatorname{Pr}(>F)$ & Mean & $95 \% \mathrm{CI}$ & $\operatorname{Pr}(>F)$ \\
\hline 90 & 8 & $0.224^{\mathrm{c}}$ & {$[0.221-0.232]$} & & $0.767^{\mathrm{a}}$ & {$[0.765-0.770]$} & & $1.71^{\mathrm{b}}$ & [1.69-1.72] & \\
\hline 100 & 8 & $0.268^{\mathrm{b}}$ & [0.264-0.275] & & $0.761^{\mathrm{b}}$ & [0.759-0.764] & & $1.74^{\mathrm{ab}}$ & [1.72-1.75] & \\
\hline 110 & 8 & $0.298^{\mathrm{a}}$ & [0.293-0.304] & & $0.758^{\mathrm{b}}$ & {$[0.755-0.760]$} & & $1.75^{\mathrm{a}}$ & [1.73-1.76] & \\
\hline Interaction & & & & 0.003 & & & 0.42 & & & 0.45 \\
\hline
\end{tabular}

${ }^{\mathrm{a}, \mathrm{b}, \mathrm{c}}$ Different letters indicate significant differences $(\mathrm{p} \leq 0.05)$.

$* \mathrm{~N}$ refers to the images acquired from four slices per each loaf. 

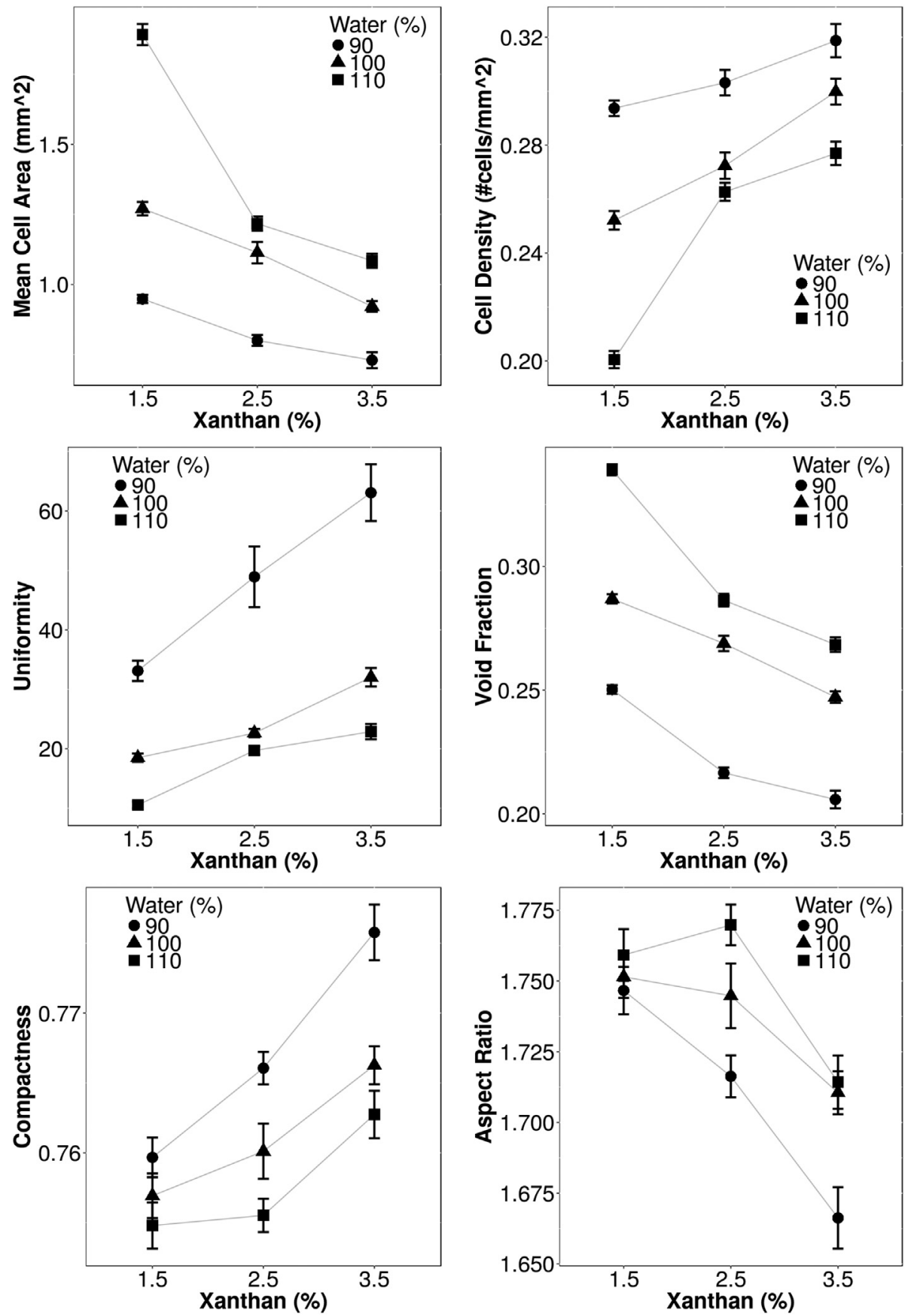

Fig. 6. Effect of xanthan gum and water content on the gluten-free bread crumb grain features of MCA (top left), CDE (top right), UNI (middle left), VFR (middle right), COM (bottom left) and ARA (bottom right).

than those obtained with the lower WC treatments. In this situation, crumb grains tend to appear more open; this is, made up of cells of greater size and less compact and more elongated shape. This leads to a less uniform grain (since the number of large cells is greater) and a higher void fraction.

A denser bread crumb grain can also be effectively evaluated by the measurements of cell size uniformity and mean cell compactness or mean cell aspect ratio. Notice that higher values of UNI and COM were obtained with higher amounts of XG (3.5\%) and lower values of WC (90\%), corresponding in both cases to a denser structure (Fig. 5). Thus, when during proofing and baking, batter expands more and steadily, a greater number of large cells is produced, therefore bringing down the ratio of small-to-large cells (UNI), while due to coalescence, the large cells tend to be more elongated and less compact, thereby bringing down the values of COM.

From the nine formulations, the more open crumb grain was attained by the formulation with $1.5 \%$ XG and $110 \%$ WC (MCA value of $1.89 \mathrm{~mm}^{2}$; Fig. 6), whereas the formulation with $3.5 \%$ XG and $90 \%$ WC produced the smallest mean cell size $\left(0.73 \mathrm{~mm}^{2}\right)$, characterising the denser structure obtained, which was also reflected by the lowest specific volume of this formulation $(1.59 \mathrm{ml} / \mathrm{g}$; Fig. 3). According to de la Hera et al. (de la Hera, Rosell, \& Gómez, 2014), if GF breads are elaborated with excessive water, large holes can appear in the crumb, as was also attested in our experiments for the formulation XG1.5/WC110 (Fig. 6).

The presence of larger cells can also be linked to a spongier crumb structure, which is a desirable bread quality property, yet not typically found in GF breads. Similar to our findings were those reported by 
Schober et al. (Schober, Messerschmidt, Bean, Park, \& Arendt, 2005) who encountered that sorghum bread with a fine crumb structure was tougher than bread with a coarse and open crumb structure. In this study, using xanthan as the only batter thickener, it was possible to obtain crumbs with open grain structures in bread loaves formulated with high level of water $(110 \%)$ and a low level of XG (1.5\%).

It is noteworthy to indicate that, in this study, the xanthan gum dose and water content were not statistically optimized, yet, with the experimental design used, a good understanding of their combined effects of the rheological and textural properties of the gluten-free bread was achieved. Futher studies can be conducted to optimise the formulation and characterise the sensorial attributes of this bread. In addition, it is desirable to elucidate the effects of other hydrocolloids such as guar gum, hydroxypropyl methylcellulose or carboxymethylcellulose, and their synergitic behaviour with xanthan gum in quinoa-based glutenfree bread.

\section{Conclusions}

Higher amounts of xanthan gum, in gluten-free bread formulated with a mixture of rice, maize and quinoa flours, have in principle the capacity to retain more water; however, at a constant water level, higher doses of xanthan gum produce less sticky batters, but of increased firmness, index of viscosity and consistency, that translates into baked loaves of reduced specific volume with a more cohesive and less springy crumb texture. On the other hand, higher doses of water content produce stickier and less viscous batters of decreased firmness and consistency, which settle into baked loaves of greater specific volume with a more cohesive and springy but softer crumb texture. The highest water content of $110 \%$ and XG between 1.5 and $2.5 \%$ produced loaves of good quality in terms of high specific volume, low hardness, high springiness, low mean cell density, low cell size uniformity, high void fraction, high mean cell aspect ratio and low mean cell compactness.

\section{Acknowledgments}

Eng. Encina-Zelada acknowledges the financial aid provided by the Peruvian National Programme of Scholarships and Student Loans (PRONABEC) in the mode of $\mathrm{PhD}$ grants (Presidente de la República-183308). Dr. Gonzales-Barron wishes to acknowledge the financial support provided by the Portuguese Foundation for Science and Technology (FCT) through the award of a five-year Investigator Fellowship (IF) in the mode of Development Grants (IF/00570). The authors are grateful to Eng. Andrea Oliveira from Prodipani, Portugal, for kindly providing breadmaking ingredients.

\section{References}

AACC International (2000). Method 10-05, approved methods of the AACC (10th ed.). St. Paul, MN: American Association of cereal chemists.

Agrahar-Murugkar, D., Gulati, P., Kotwaliwale, N., \& Gupta, C. (2015). Evaluation of nutritional, textural and particle size characteristics of dough and biscuits made from composite flours containing sprouted and malted ingredients. Journal of Food Science and Technology, 52(8), 5129-5137.

Anonymous (2012). The gluten-free agency. Ontario, Canada. Access, 22. May 2018. Available at http://thegluten-freeagency.com/why-a-gluten-free-agency/.

Bhatt, S. M., \& Gupta, R. K. (2015). Bread (composite flour) formulation and study of its nutritive, phytochemical and functional properties. Journal of Pharmacognosy and Phytochemistry, 4(2), 254-268.

Burešová, I., Masaříková, L., Hřivna, L., Kulhanová, S., \& Bureš, D. (2016). The comparison of the effect of sodium caseinate, calcium caseinate, carboxymethyl cellulose and xanthan gum on rice-buckwheat dough rheological characteristics and textural and sensory quality of bread. LWT - Food Science and Technology, 68, 659-666.

Cornejo, F., \& Rosell, C. M. (2015). Physicochemical properties of long rice grain varieties in relation to gluten free bread quality. LWT - Food Science and Technology, 62(2), 1203-1210.

Devi, P. B., Kavitake, D., \& Shetty, P. H. (2016). Physico-chemical characterization of galactan exopolysaccharide produced by Weissella confusa KR780676. International Journal of Biological Macromolecules, 93, 822-828.

Diekjürgen, D., \& Grainger, D. W. (2017). Review: Polysaccharide matrices used in 3D in vitro cell culture systems. Biomaterials, 141, 96-115.
Funami, T., Kataoka, Y., Omoto, T., Goto, Y., Asai, I., \& Nishinari, K. (2005). Food hydrocolloids control the gelatinization and retrogradation behavior of starch. 2a. Functions of guar gums with different molecular weights on the gelatinization behavior of corn starch. Food Hydrocolloids, 19(1), 15-24.

Ghodke, S. K. (2009). Effect of guar gum on dough stickiness and staling in chapatti-an Indian unleavened flat bread. International Journal of Food Engineering, 5(3), 7.

Gonzales-Barron, U., \& Butler, F. (2006). A comparison of seven thresholding techniques with the k-means clustering algorithm for measurement of bread-crumb features by digital image analysis. Journal of Food Engineering, 74(2), 268-278.

Gonzales-Barron, U., \& Butler, F. (2008). Discrimination of crumb grain visual appearance of organic and non-organic bread loaves by image texture analysis. Journal of Food Engineering, 84(3), 480-488.

Gujral, N., Freeman, H. J., \& Thomson, A. B. R. (2012). Celiac disease: Prevalence, di agnosis, pathogenesis and treatment. World Journal of Gastroenterology, 18(42), 6036-6059.

Hager, A.-S. (2013). Cereal products for specific dietary requirements, Evaluation and improvement of technological and nutritional properties of gluten free raw materials and end products. Ireland: University College Cork (PhD Thesis).

Hager, A.-S., \& Arendt, E. K. (2013). Influence of hydroxypropylmethylcellulose (HPMC), xanthan gum and their combination on loaf specific volume, crumb hardness and crumb grain characteristics of gluten-free breads based on rice, maize, teff and buckwheat. Food Hydrocolloids, 32, 195-203.

Hager, A.-S., Wolter, A., Czerny, M., Bez, J., Zannini, E., Arendt, E. K., \& Czerny, M. (2012). Investigation of product quality, sensory profile and ultrastructure of breads made from a range of commercial gluten-free flours compared to their wheat counterparts. European Food Research and Technology, 235(2), 333-344.

Han, H. M., Cho, J. H., Kang, H. W., \& Koh, B. K. (2012). Rice varieties in relation to rice bread quality. Journal of the Science of Food and Agriculture, 92(7), 1462-1467.

Horstmann, S. W., Axel, C., \& Arendt, E. K. (2018). Water absorption as a prediction tool for the application of hydrocolloids in potato starch-based bread. Food Hydrocolloids, 81, 129-138.

Juszczak, L., Witczak, T., Ziobro, R., Korus, J., Cieślik, E., \& Witczak, M. (2012). Effect of inulin on rheological and thermal properties of gluten-free dough. Carbohydrate Polymers, 90(1), 353-360.

de la Hera, E., Rosell, C. M., \& Gómez, M. (2014). Effect of water content and flour particle size on gluten-free bread quality and digestibility. Food Chemistry, 151, $526-531$.

Li, J.-M., \& Nie, S.-P. (2016). The functional and nutritional aspects of hydrocolloids in foods. Food Hydrocolloids, 53, 46-61.

Machado-Alencar, N. M., Steel, C. J., Alvim, I. D., Carvalho de Morais, E., \& Andre-Bolini, H. M. (2015). Addition of quinoa and amaranth flour in gluten-free breads: Temporal profile and instrumental analysis. LWT - Food Science and Technology, 62(2), 1011-1018.

Marti, A., Marengo, M., Bonomi, F., Casiraghi, M. C., Franzetti, L., Pagani, M. A., \& Iametti, S. (2017). Molecular features of fermented teff flour relate to its suitability for the production of enriched gluten-free bread. LWT - Food Science and Technology, $78,296-302$.

Martínez, M. M., \& Gómez, M. (2017). Rheological and microstructural evolution of the most common gluten-free flours and starches during bread fermentation and baking. Journal of Food Engineering, 197, 78-86.

McNeish, D. M., \& Harring, J. R. (2017). Clustered data with small sample sizes: Comparing the performance of model-based and design-based approaches. Communications in Statistics: Simulation and Computation, 46(2), 855-869.

Mir, N. A., Riar, C. S., \& Singh, S. (2018). Nutritional constituents of pseudo cereals and their potential use in food systems: A review. Trends in Food Science \& Technology, 75, 170-180.

Naqash, F., Gani, A., Gani, A., \& Masoodi, F. A. (2017). Gluten-free baking: Combating the challenges - A review. Trends in Food Science \& Technology, 66, 98-107.

Onyango, C., Mutungi, C., Unbehend, G., \& Lindhauer, M. G. (2011). Modification of gluten-free sorghum batter and bread using maize, potato, cassava or rice starch. LWT - Food Science and Technology, 44(3), 681-686.

Pasqualone, A., Caponio, F., Summo, C., Paradiso, V. M., Bottega, G., \& Pagani, M. A. (2010). Gluten-free bread making trials from cassava (Manihot esculenta Crantz) flour and sensory evaluation of the final product. International Journal of Food Properties, $13,562-573$.

Pellegrini, M., Lucas-Gonzales, R., Ricci, A., Fontecha, J., Fernández-López, J., PérezÁlvarez, J. A., \& Viuda-Martos, M. (2018). Chemical, fatty acid, polyphenolic profile, techno-functional and antioxidant properties of flours obtained from quinoa (Chenopodium quinoa Willd) seeds. Industrial Crops and Products, 111, 38-46.

Peressini, D., Pin, M., \& Sensidoni, A. (2011). Rheology and breadmaking performance of rice-buckwheat batters supplemented with hydrocolloids. Food Hydrocolloids, 25(3), 340-349.

R Core Team (2017). R: A language and environment for statistical computing. Vienna, Austria: R Foundation for Statistical Computing. Available online at http://www.Rproject.org/, Accessed date: 2 April 2018.

Renzetti, S., \& Rosell, C. M. (2016). Role of enzymes in improving the functionality of proteins in non-wheat dough systems. Journal of Cereal Science, 67, 35-45.

Rinaldi, M., Paciulli, M., Caligiani, A., Scazzina, F., \& Chiavaro, E. (2017). Sourdough fermentation and chestnut flour in gluten-free bread: A shelf life evaluation. Food Chemistry, 224, 144-152.

Ruiz, G. A., Xiao, W., van Boekel, M., Minor, M., \& Stieger, M. (2016). Effect of extraction $\mathrm{pH}$ on heat-induced aggregation, gelation and microstructure of protein isolate from quinoa (Chenopodium quinoa Willd). Food Chemistry, 209, 203-210.

Sabanis, D., \& Tzia, C. (2011). Effect of hydrocolloids on selected properties of gluten-free dough and bread. Food Science and Technology International, 17(4), 279-291.

Sanguinetti, A. M., Secchi, N., Del Caro, A., Fadda, C., Fenu, P. A. M., Catzeddu, P., \& 
Piga, A. (2015). Gluten-free fresh filled pasta: The effects of xanthan and guar gum on changes in quality parameters after pasteurisation and during storage. LWT - Food Science and Technology, 64, 678-684.

Schober, T. J., Messerschmidt, M., Bean, S. R., Park, S.-H., \& Arendt, E. K. (2005). Glutenfree bread from sorghum: Quality differences among hybrids. Cereal Chemistry, 82(4), 394-404.

Sciarini, L., Ribotta, P., León, A., \& Pérez, G. (2012). Incorporation of several additives into gluten free breads: Effect on dough properties and bread quality. Journal of Food Engineering, 11(4), 590-597.
Sciarini, L. S., Ribotta, P. D., León, A. E., \& Pérez, G. T. (Ribotta, León and Pérez, 2010a). Effect of hydrocolloids on gluten-free batter properties and bread quality. International Journal of Food Science and Technology, 45(11), 2306-2313.

Sciarini, L. S., Ribotta, P. D., León, A. E., \& Pérez, G. T. (Ribotta, León and Pérez, 2010b), Influence of gluten-free flours and their mixtures on batter properties and bread quality. Food and Bioprocess Technology, 3(4), 577-585.

Turkut, G. M., Cakmak, H., Kumcuoglu, S., \& Tavman, S. (2016). Effect of quinoa flour on gluten-free bread batter rheology and bread quality. Journal of Cereal Science, 69, 174-181. 